\title{
Challenges of Utilizing E-Learning Systems in Public Universities in Jordan
}

\author{
doi:10.3991/ijet.v5i2.1147 \\ Dr. Muhannad Al-Shboul ${ }^{1}$, Dr. Izzat Alsmadi ${ }^{2}$ \\ ${ }^{1}$ The University of Jordan, Amman, Jordan \\ ${ }^{2}$ Yarmouk University, Irbid, Jordan
}

\begin{abstract}
This research paper lists and discusses major challenges and barriers that may face faculty members at the public universities in Jordan in employing e-Learning systems authoring tools in their instructions. It also proposes several suggestions for the administrators in public universities in Jordan for what they could do to improve the utilization of e-Learning authoring tools at their campuses. E-Learning systems authoring tools allow instructors to easily create and deliver their e-contents and e-lectures. Furthermore, online course materials which uploaded by using such authoring tools could be viewed by any popular web browser system.
\end{abstract}

Keywords-E-content/e-course, e-Learning, e-lecture, and web-based authoring tools.

\section{INTRODUCTION}

Despite the fact that e-Learning has been around for ten years or so, it becomes a service offered by most colleges and universities all over the world. E-Learning mainly takes the form of online courses, training, and services whereby the courses, training, and services are organized and delivered via online (e.g. Blackboard, Webboard, WebCT, LiveText, Moodle, self-created course/training Webpage, and other e-Learning authoring systems). While e-Learning systems are becoming widely spread in higher education institutions, many such institutions are focusing on providing electronic course content (e-lectures) besides various services to their students, faculty, and staff. Most of the burden in offering these services such as communications, e-registration, and online exams is in getting the right platform and securing its database communications; whereas, the main burden in offering e-lectures is in composing the content in an electronic format that could be uploaded through the adopted platform, viewed by all students, and easily composed [1].

Jordan is considered one of the pioneer countries in the Middle East in the information technology sector, in general, and in the make use of technology in education, in particular [2]. The use of technology in education has been steadily growing in Jordan with a recent push from the government level. For that reason, Jordan's first eLearning forum, held in 2003, emphasized that the educational reforms and the integration of information technology in the educational process are the most important elements in the Jordan's modernization drive. However, the overall progress in the use of e-Learning systems in the higher education institutions in Jordan is still relatively behind expectations.

In what follows, the research paper will introduce an overview on e-Learning systems as well as identify some of the essential e-Learning system services and features. The research paper then presents some of the challenges that are associated with the use of e-Learning systems authoring tools at the public universities in Jordan. The last part of the research paper focuses on how to improve the utilization of e-Learning authoring tools by provide some suggestions regarding the current and future use of e-Learning systems services in the higher education environment in Jordan. But first, let us have a look at some available and related work in both the literature and the market to e-Learning systems and e-Lectures authoring tools, respectively.

It is important to point out that the term "e-Learning systems" and "e-Learning management systems" are considered synonyms throughout this document.

\section{E-LEARNING SYSTEMS OVERVIEW}

\section{A. A Review of Literature on e-Learning Management} Systems

E-Learning systems, also called e-Learning management systems, are Web-based software that manage student enrollment, track student performance, and create and distribute course content. The main purpose of e-Learning systems packages is to enable faculty and educators to create course Web sites, that is to place course materials online and manage course activities [3]. E-Learning systems are tools faculty can use to create online course content (without knowing programming languages), communicate electronically with students, and conduct assessments [4]. According to Stockley [5], e-Learning is the delivery of a learning, training or education program by electronic means; involves the use of a computer or electronic device in some way to provide training, educational or learning material.

The integration of e-Learning systems in higher education has been an important issue recently [6]. Consequently, e-Learning systems have become an invaluable tool for teaching with technology. Three aspects of eLearning systems make it an extraordinary tool for ordinary instructors. First, the files are all kept on e-Learning systems servers. The second feature, invaluable to instructors, is that the entire course can be archived for future use. The third feature, the convenience, is that the user can access the course materials from anywhere, at any time [7].

Like all technology, e-Learning systems authoring tools (such as Blackboard, Webboard, WebCT, LiveText, Moodle, and others) have their own advantages and disadvantages. Some of the main advantages of e-Learning systems authoring tools are convenience, flexibility, ac- 
cessibility, and cost-effectiveness [8]. Accordingly, some public universities in Jordan have started to incorporate some E-learning systems authoring tools, like Blackboard, at their campuses. However, the level of such technology integration in the higher education institutions in Jordan is less than expected. This probably due to several reasons such as faculty are reluctant to accept technology integration or use these tools in their teaching. Therefore, it becomes critical to review the related literature regarding why faculty, in general, and at public universities in Jordan, in particular, choose to use or not to use these tools for their course support.

Before doing so, initially, the research paper will discuss the most common tools and application packs for the academic suite, such as the Blackboard, that the eLearning systems offer. Figure 1 shows some basic tools of the Blackboard. The indicated figure illustrates the Blackboard Control Panel page, which only instructors and their designated assistants can access [9]. The Control Panel is divided into six areas: Content Areas, Course Tools, Course Options, User Management, Assessment, and Support. Content Areas provides the tools necessary to add text, files, and information to the course. Course Tools contains the communication tools for instructors to send email, create tasks, and work with groups; this area also contains Building Blocks. Course Options contains security and customization options for management of course components. User Management provides tools for the instructor to manage users and enrollments. Assessment provides tools for creating tests and surveys, recording grades, and tracking user activity. Support offers support contacts and online documentation.

\begin{tabular}{|c|c|}
\hline \multicolumn{2}{|l|}{ Content Areas } \\
\hline Syllabus & Assignments \\
\hline Course Documents & External Links \\
\hline \multicolumn{2}{|l|}{ Course Tools } \\
\hline Announcements & Digital Drop Box \\
\hline Course Calendar & Messages \\
\hline Staff Information & Glossary Manager \\
\hline$\underline{\text { Tasks }}$ & Advanced Group Management \\
\hline Discussion Boards & Link Checker \\
\hline Send E-mail & Batch Group Management \\
\hline \multicolumn{2}{|l|}{ Collaboration } \\
\hline \multicolumn{2}{|l|}{ Course Options } \\
\hline Manage Course Menu & Import Package \\
\hline Manage Tools & Export Course \\
\hline Settings & Archive Course \\
\hline Impert Course Carttidge & Resources \\
\hline \multicolumn{2}{|l|}{ User Management } \\
\hline List / Modify Users & Remove Users from the Course \\
\hline Enroll User & $\underline{\text { Manage Groups }}$ \\
\hline \multicolumn{2}{|l|}{ Assessment } \\
\hline Test Manager & Gradebook \\
\hline Survey Manager & Gradebook Views \\
\hline Pool Manager & Course Statistics \\
\hline \multicolumn{2}{|l|}{ Support } \\
\hline \multicolumn{2}{|l|}{ Support } \\
\hline \multicolumn{2}{|l|}{ Manual } \\
\hline Contact System Adminis & \\
\hline
\end{tabular}

Figure 1. Basic Blackboard Control Panel Tools
In addition to these Blackboard basic tools, as has been mentioned previously, there are some other additional tools that available by most of e-Learning management systems. Some of these additional tools, for academic purposes, are: Course Management, Content Authoring, Adaptive Release, Syllabus Builder, Learning Units, Teaching and Learning Tools, Personal Information Management, Discussion Board, Collaboration Tools, Group Projects, Assessments and Surveys, Assignments, Gradebook, Community Building Tools, Role-Based Information Delivery, Multi-institution Branding, e-Commerce, eMarketplace, Content and File Management, Versioning, Disk Space Bandwidth Management, Collaborative Webenabled File Storage, ePortfolios, and Multi-Language Support [10]. A listing of e-Learning management systems features/tools will be discussed in greater detail in a later part of this paper.

E-Learning management systems also provide information on just about anything the academic institution needs to track and analyze about students, faculty, and staff; former students, faculty, and staff; and applicants. The academic institution can select an e-Learning system and customize it to meet its needs. Such system could contain tools for data entry, data tracking, and data information needs of the Human Resources, payroll, management, and accounting functions within the academic institution.

With an appropriate e-Learning system, Human Resources employees enables faculty members and staff to do their own benefits updates and address changes, thus freeing Human Resources employees for more strategic functions. Additionally, data necessary for employee management, knowledge development, career growth and development, and equal treatment is facilitated.

Furthermore, such e-Learning system enable academic administrators to access the information they need to legally, ethically, and effectively support the success of their reporting faculty members and staff [11]. Overall, an effective e-Learning system provides employee self service, for academic and administrative staff, such as view personal information, update eProfile, view payroll and compensation information, view benefits, request paid time off, and offer help and more information for how to access the system. Hence, efficient e-Learning systems can be used by academic institutions for both academic and nonacademic purposes at the same time.

On the one hand, Blackboard Academic Suite software is used to manage E-Learning. Among the features that the Blackboard Academic Suite offers is to provide the instructors with the ability to create and manage course content, utilize publisher content, evaluate performance, and communicate with students. However, Blackboard is not an open source system; it is available at a price considered by many academic institutions as an expensive system to use. Furthermore, the content or lectures developed using such systems, in most cases, cannot be used elsewhere; thus, leaving the institution under a long-term agreement with the vendors of these systems.

On the other hand, Moodle is an open source software package designed using sound pedagogical principles, to help educators create effective online learning/training materials and Web-based courses. It is an ongoing development project designed to support a social constructionist framework of education [12]. Moodle has many features that are valuable for most educational institutions. Such 
features include: Question engine, Assignment types, Activity modules, and Course formats. Thus, Moodle is becoming more and more popular. After all, it is free and allows users to enhance its feature set.

In conclusion, a review of literature shows that many articles have been written comparing the functionality of different e-Learning authoring tools; however, the level of faculty use of e-Learning management systems and/or the challenges of utilizing such authoring tools in academia have rarely been addressed, in general, and in Jordan, in particular. Some scholars highlight a need to explore such issues. Therefore, this study identified challenges related to the utilization of e-Learning authoring tools at the higher education institutions in Jordan. Specifically, the purpose of this study was to investigate what public universities' administrators in Jordan can do to improve the utilization of e-Learning management systems at their campuses.

\section{B. An Overview on Authoring Systems}

There are several methods to create an e-content for Web-based courses. Creating static or dynamic web pages with PHP or HTML; using specific application development, such as Java applets; or using multimedia production tools, such as Macromedia Flash, Macromedia Authorware, and Multimedia Toolbox are the most common methods for content creation for e-lecture use. The main disadvantage of these methods is the high cost of development. Systems for the creation of e-Lecture during a normal lecture were developed to avoid such high costs. Interactive Whiteboard is an example of such systems; it allows instructors to record their instruction and post the material for review by students at a later time [13].

Thus, lightweight content production using presentation recording instead of traditional authoring systems has become an increasingly popular method of creating instructional media or electronic material for offline use. The main objective of content production by presentation recording is to automatically capture live lectures and presentations in classrooms and lecture halls, make them available as e-Lectures in a variety of output formats for access over the internet or on demand. The major advantage of these systems is the reduced costs for the creation of electronic course content [1].

Today, a number of commercial products make automatic presentation recording available to a wider, nontechnical user community [14]. The disadvantage that may arise using the available systems is the unsatisfactory tradeoff between the size of the resulted e-Lecture and the loss of significant animations and notations. However, using these systems, the viewers, students, or whoever wants to retrieve courses materials via the Internet may find it difficult to access the electronic content or the outcome. This is due to the need of installing special programs to access the content. Hence, e-Learning systems have become a solution to such issue [15].

\section{E-LEARNING SYSTEMS TOOLS}

As mentioned earlier, Blackboard e-Learning system is an online course management program which allows instructors to create, deliver, and manage web-based components for courses. It can be used to add online elements to a traditionally delivered face-to-face course, or to develop completely online courses with few or no face-toface meetings. One accepted standard to develop e-
Learning systems is the IMS (Instructional Management Systems), a global learning consortium that develops and promotes the adoption of open technical specifications for interoperable learning technologies that become the standards for delivering learning products worldwide [16].

Application Packs for e-Learning management systems provides a common set of features/tools that are briefed in Table I. Table I summarizes the functions for most of the tools that most e-Learning systems contain. However, such system usually offers various services to various users depending on the role they would be playing. Eight differed roles could be offered. These roles are: Student, Instructor, Head of Department, Dean, Registrar, Advisor, Embassy (or sponsor), and administrator. The next section of this research paper discusses the challenges of the utilization of e-Learning systems in higher education, in general, and in Jordan, in particular.

TABLE I.

E-LEARNING SYSTEMS APPLICATION PACKS

\begin{tabular}{|c|c|}
\hline Tool & Function \\
\hline Course Management & $\begin{array}{l}\text { Course Management capabilities focus on } \\
\text { effective creation and set-up of courses }\end{array}$ \\
\hline Content Authoring & $\begin{array}{l}\text { QuickEdit allows an instructor to quickly } \\
\text { switch between the student view of a course } \\
\text { content area and the instructor view }\end{array}$ \\
\hline Adaptive Release & $\begin{array}{l}\text { Content items, discussions, assessments, } \\
\text { assignments, or other activities can be re- } \\
\text { leased to students based on a set of criteria }\end{array}$ \\
\hline Syllabus Builder & $\begin{array}{l}\text { Provides the ability for instructors to easily } \\
\text { create a course syllabus }\end{array}$ \\
\hline Learning Units & $\begin{array}{l}\text { Allows instructors to create sequenced les- } \\
\text { sons and control students' progress through } \\
\text { the Learning Unit }\end{array}$ \\
\hline $\begin{array}{l}\text { Teaching and Learning } \\
\text { Tools }\end{array}$ & $\begin{array}{l}\text { A variety of tools designed for support of } \\
\text { specific teaching or learning activities }\end{array}$ \\
\hline $\begin{array}{l}\text { Personal Information } \\
\text { Management }\end{array}$ & $\begin{array}{l}\text { Provides usage statistics for individual con- } \\
\text { tent items }\end{array}$ \\
\hline Discussion Board & $\begin{array}{l}\text { Instructors can set up multiple forums around } \\
\text { different topics and embed those forums in } \\
\text { appropriate content areas or lessons }\end{array}$ \\
\hline Collaboration Tools & $\begin{array}{l}\text { The Virtual Classroom provides a collabora- } \\
\text { tive whiteboard, group web brows- } \\
\text { ing/touring, private question-and-answer, } \\
\text { and breakout room capability }\end{array}$ \\
\hline Group Projects & $\begin{array}{l}\text { To support peer collaboration, instructors can } \\
\text { use the Groups tool to form multiple groups } \\
\text { of students }\end{array}$ \\
\hline $\begin{array}{l}\text { Assessments and Sur- } \\
\text { veys }\end{array}$ & $\begin{array}{l}\text { Instructors can create assessments from } \\
\text { scratch or draw upon personal, institutional, } \\
\text { or commercially-available "test banks" of } \\
\text { questions }\end{array}$ \\
\hline Assignments & $\begin{array}{l}\text { Instructors can track the students' assign- } \\
\text { ments and download the submissions from } \\
\text { an entire class simultaneously through the } \\
\text { Gradebook }\end{array}$ \\
\hline Gradebook & $\begin{array}{l}\text { The Gradebook supports custom grading } \\
\text { scales, grade weighting, item analysis, and } \\
\text { multiple gradebook views }\end{array}$ \\
\hline ePortfolios & $\begin{array}{l}\text { Enable students and faculty members to } \\
\text { assemble, present and share information } \\
\text { online for documenting academic growth and } \\
\text { career evaluation }\end{array}$ \\
\hline $\begin{array}{l}\text { Multi-Language Sup- } \\
\text { port }\end{array}$ & $\begin{array}{l}\text { Instructors can set the language of the course } \\
\text { independently from the language setting of } \\
\text { the overall system }\end{array}$ \\
\hline
\end{tabular}




\section{E-LEARNING MAJOR CHALLENGES}

Identifying the challenges toward the use of e-Learning management systems in higher education may lead to a better understanding of the causes of reluctance to eLearning use. Thus, this part of the paper presents the challenges, obstacles, and barriers for implementing eLearning systems in higher education institutions. However, because there has been little written about this issue, in general, and within the context of Jordan, in particular, the indicated challenges were formulated based on the reviewed literature. For future work, the authors will conduct another study, specifically, to investigate the factors that are encounter for such challenges in the higher education sector in Jordan.

Yet little is known about the challenges to implementing e-Learning systems, in general, and in public universities in Jordan, in particular. Little research has been conducted about identifying the challenges that may operate as barriers to adopt e-Learning systems for teaching and learning [17]. However, some of the reviewed literature identified that the problems facing higher education faculty in integrating e-Learning tools into their classes need to be addressed to improve the level of e-Learning management systems utilization.

Academic institutions spend a lot of money for every year on the use of technology in education. Therefore, research on the uses of technology in instruction is important because the findings will help understand technology integration. In addition, the obtained data can help in determining what academic institutions can do to improve technology integration at their campuses because the level of technology integration has become a source of data upon which to evaluate university performance and reputation [18].

Higher education institutions face persistent challenges in the use of technology, with the e-Learning management systems being the latest technology challenge. Getting a new idea adopted, even when it has obvious advantages, is difficult [19]. Accordingly, adapting new technological innovation, such as e-Learning systems, in higher education requires faculty to change their ways of teaching; such change does not come easily [20]. In this regard, the reviewed literature indicates that one of the major problems hindering the use e-Learning systems in higher education is faculty reluctance [21].

The reviewed literature identified some challenges for implementing -Learning systems tools in the institutions of higher education, which are due to a number of different issues [22]. The most common challenges are: faculty members hesitate to change; some faculty members do not have the skills to use e-Learning systems, and are not especially eager to learn; and there is an institutional reluctance to provide sufficient personnel and financial assistance to facilitate the use of such technology. Other challenges is that timely faculty development, support, and learning materials are required to integrate e-Learning tools effectively; moreover, potential users are often reluctant to acquire the skills for using such technology.

One of the other challenges for implementing eLearning systems in higher education is that some instructors may have felt threatened by change, so chose to resist e-Learning systems. Also, little formal effort was made to support instructors who tried to implement e-Learning systems [23]. Additionally, some faculty members are reluctant to adopt e-Learning systems because they believe the systems reduce their control of instruction and the instructional environment. Some faulty members and university administrators do not believe that e-Learning management systems fulfill their needs. Some literature indicated that the organizational cultures, norms, and planning are affecting the utilization of e-Learning systems [24].

The rest of the challenges for implementing e-Learning management systems in the academic institutions, according to the reviewed literature, can be summarized as the following: characteristics of e-Learning systems; protection of intellectual property rights; royalties on copyrighted materials; technological background; concern about students' technological skills; concern about loss of control over teaching process; concern about faculty workload; concern about faculty role; lack of monetary support; lack of adequate training in the use of e-Learning systems; lack of salary increase; lack of release time; lack of time to learn e-Learning systems; lack of technical support provided by the institution and, most importantly, a perceived lack of institutional encouragement, support, and incentives [25].

Hence, all of the indicated factors, based on the reviewed literature, are play a major role in the level of utilizing e-Learning management systems in higher education institutions, including Jordan. They considered as challenges for implementing such systems/tools. However, it is important to point out that those challenges not only applied to the international academic institutions, but also are applied to the academic institutions in Jordan as well. Because Jordan has almost the same academic atmosphere comparing to that of the international one; also, because it is utilizing almost the same e-learning systems and authoring tools. Nevertheless, there is a need for conducting a study specifically for the academic institutions in Jordan to confirm these findings.

\section{DISSCUSION AND IMPLICATIONS}

The reviewed literature indicated that there is a relationship between academic institutional support and the level of the utilization of e-Learning systems, the more the academic institutional support, the more likely faculty members are to use e-Learning systems [26]. Therefore, in this section, the research paper discusses how to improve the utilization of e-Learning systems and what academic institutions can do to reduce, minimize, or overcome the obstacles and challenges for implementing e-Learning systems at their campuses.

The reviewed literature, clearly, indicated that institutional support and encouragement and faculty training are essential factors for successful implementation of eLearning systems in higher education teaching and learning environments. Furthermore, strong leadership by campus executives and department chairs plays an important role in shaping and encouraging faculty to use e-Learning systems tools [27].

The reviewed literature indicated that faculty attitudes toward e-Learning technology need to be identified, discussed, and addressed, whenever possible to overcome the challenges for implementing e-Learning systems in higher education. Should higher education institutions decide to become more involved in the use of e-Learning systems 
tools, then faculty participation as well as additional research will be essential.

A lack of institutional support, a lack of time to learn eLearning technology (workload), and a lack of knowing how to utilize e-Learning technology were found to be some of the major challenges for implementing eLearning management systems in academia [8]. Consequently, academic institutions should: offer more training sessions in the use of e-Learning systems tools; offer workshops concerning the technical issues in using eLearning systems tools; and reduce teaching loads to make more time available for employing e-Learning systems tools.

Additionally, to improve the level of the utilization of e-Learning management systems and to minimize the level of challenges for implementing such tools, academic institutions should: offer rewards and incentives for using e-Learning systems tools; offer adequate encouragement and support concerning the use of e-Learning systems tools such as establishing or activating faculty development programs that focus on the use of e-Learning systems tools; and protect the intellectual property rights of its faculty members by having copyrighted material policies recognizing the faculty members as the owners of the courses they develop, which is critical to increase the use of e-Learning systems tools. Lastly, academic institutions should provide a stipend, merit pay, or an increase in salary for faculty who use e-Learning systems tools in their classes.

In short, faculty play an important role in the implementation of e-Learning systems tools and technological change in higher education. However, as indicated earlier, faculty involvement in the use of e-Learning systems tools is influenced by multiple factors, both motivating and inhibiting. Currently, it is presumed that most universities worldwide are in a position to either increase their involvement or to continue their current levels of involvement in the use of e-Learning systems tools.

The research paper findings, based on the considerations of the literature and expert opinions, have implications for administrations of public universities in Jordan and may provide areas of consideration for educators in other higher education institutions and, specifically, for eLearning systems practitioners (users and non-users) in higher education. The findings imply that personal experience with e-Learning systems tools is an influential factor in individuals' attitudes toward e-Learning systems use. If e-Learning systems diffusion strategies and efforts are to be promoted and expanded, it is important that faculty are provided with the opportunity to engage in a positive eLearning systems use experience. This may be accomplished in several ways: (1) Define what obstacles need to be overcome to ensure the success of e-Learning systems use in higher education environments. Also provide adequate training for faculty who utilize or would utilize a course using e-Learning systems tools; such training opportunities should be publicized. This is important because training in e-Learning systems use is essential to encourage higher levels of faculty use and more effective uses of the technology. (2) Provide institutional encouragement, support, and incentives for faculty who desire to use e-Learning systems tools. Also implement an intellectual property agreement that will allow faculty to retain rights to the material they have created. (3) Offer a handson learning experience to faculty who express a desire to use e-Learning systems tools; such learning experience could be included as part of the introductory tour provided by institutions to all incoming faculty members. (4) Encourage and reward faculty for exemplar uses of CMS tools to support instruction. Also reduce the faculty workload and provide faculty with more time to develop and use e-Learning systems tools. (5) Address the factors discussed in this paper (motivating and inhibiting) and monitor them if the academic institutions want to expand the eLearning systems use at their campuses. Individuals who are designing and implementing e-Learning systems, such as faculty development directors, should consider these factors in the development of appropriate e-Learning systems diffusion strategies. The findings of this research paper suggest that these factors are important in determining faculty attitude toward the use of e-Learning systems tools, as well as willingness to use e-Learning systems tools. (6) Create university-level policies on the use of eLearning systems tools and establish college-level policies on the use of e-Learning systems tools for each academic discipline. Institutional policies on the use of e-Learning systems tools are important in attracting and retaining faculty to participate in the use of e-Learning systems tools. (7) Provide a comprehensive e-Learning systems program to combat the resistant attitudes of e-Learning systems faculty non-users. To implement e-Learning systems tools, faculty must perceive that using e-Learning systems has a relative advantage over not using eLearning systems. Therefore, faculty development programs should make faculty aware of the many advantages of e-Learning systems, such as convenience, flexibility, accessibility, and cost-effectiveness. In addition, for eLearning systems to succeed, e-Learning systems faculty non-users need to perceive e-Learning systems as being compatible with their current teaching methods. The comprehensive e-Learning systems program should illustrate how e-Learning systems tools can be integrated into several teaching methods. (8) Encourage appropriate assessment and evaluation of the impact of e-Learning systems tools on the teaching and learning process because the cost of technology and time needed to learn how to use such tools properly are critical for academic institutions. (9) Provide a stipend, merit pay, or an increase in salary for faculty who use e-Learning systems tools in their classes. And (10) provide release time or reduce teaching load for faculty who use e-Learning systems tools in their classes.

In summary, defining what obstacles and challenges that needed to be overcome is important to ensure the success of e-Learning systems utilization in higher education environments.

\section{CONCLUSION AND FUTURE WORK}

A core group of tools are available with essentially all e-Learning management systems. These core components included tools for synchronous and asynchronous communication; content storage and delivery; online quiz and survey tools; gradebooks; whiteboards; digital dropboxes; and email communications. Some faculty members are using e-Learning systems tools to supplement their traditional classroom instruction [28].

Public universities in Jordan took several steps toward the utilization of e-Learning management systems at their campuses. However, the extent to which they use the full range of e-Learning systems tools is less than many may have anticipated, but use is growing rapidly. 
The goal of this research paper was to investigate the challenges that are related to the utilization of e-Learning management systems in higher education, completely, and in Jordan, partially. However, major conclusions emerge from this research paper; there are several challenges affecting the level of the use of e-Learning management systems in higher education institutions, including Jordan.

On the one hand, lack of institutional incentives for using e-Learning systems tools, e-Learning systems is difficult to utilize without the proper training, and adequate institutional support are the most major challenges for utilizing e-Learning systems tools in academia. On the other hand, an increase in salary, receiving a stipend for using e-Learning systems, receiving a recognition/reward from the administration, merit pay, release time, teaching workload, and training in the use of e-Learning systems are the most common requirements that needed by faculty to improve the utilization of e-Learning management systems at university campuses.

Based on the indicated conclusions, this research paper suggests that, in order to overcome the challenges for implementing e-Learning systems in public universities in Jordan, faculty need financial incentives to encourage them to use e-Learning systems tools; faculty need training, technical assistance, and institutional support to enable them to use e-Learning systems tools; and faculty need more information about the effectiveness of eLearning systems tools for instruction.

Should higher education institutions in Jordan decide to become more involved in the use of e-Learning systems tools, then faculty participation as well as institutional support will be essential. To use e-learning systems effectively in Jordan, the public universities must enhance the technical proficiency of its faculty and staff, and develop a reliable and robust technical infrastructure. Towards this step, public universities in Jordan should develop elearning infrastructure, training, course development, and support practices; all of these could be achieved by establish an E-learning Center at the university campuses.

Based on the discussion, this research paper suggests several areas for future research. Conduct a follow-up study on faculty uses of e-Learning systems in instruction at one of the public universities in Jordan to verify the findings of this research paper. The obtained data, from such study, can provide information about what academic institutions in Jordan can do to reduce, minimize, or overcome the obstacles and challenges for implementing eLearning systems at their campuses because the level of technology integration has become a source of data upon which to evaluate university performance and reputation.

Conduct a study at one of the public universities in Jordan to examine the identified challenges related to the use of e-Learning systems tools. Furthermore, conduct a study to investigate the administrative leadership role in shaping and encouraging faculty use of e-Learning management systems. Last but not least, because some faculty members who currently do use e-Learning systems, whereas, others who do not, it is highly recommended to conduct a study in one of the public universities in Jordan to identify factors that differentiate faculty users versus non-users of eLearning management systems tools. However, a Webbased survey will be used as a primary source for data collection for the recommended future studies that the authors are intended to conduct. In this regard, for the first, second, and third study, descriptive research can be used as a methodology to answer the research questions. This type of methodology provides accurate, reliable, and generalizable results about a topic when little is known beforehand. Whereas, for the fourth study, a correlation is recommended to be used as a statistical technique to compare the relationship between faculty users and non-users and each of the following variables: faculty age, gender, rank, experience with using e-Learning systems, motivating factors, inhibiting factors, institutional support, and attitudes toward the use of e-Learning systems tools. However, explorative studies, comparing various methodologies of implementation, instructors training needs, pedagogical approaches, and the learners' perspectives are highly recommended and should be taken into consideration when conducting such suggested future studies.

Last but not least, this study is considered as a cornerstone for another study which will be conducted at the beginning of April 2010 in one of the public universities in Jordan by the researchers to verify the findings of the reviewed literature as they revealed in this paper.

\section{REFERENCES}

[1] Hirzallah, N. (2007). An Authoring Tool for As-in-Class Electures in E-Learning Systems. American Journal of Applied Sciences, 4 (9), 686-692. doi:10.3844/ajassp.2007.686.692

[2] Al-Smadi, I., \& Al-Shboul, M. (2008). Challenges of Implementing Digital Certificates in Jordan and its impact on e-business. Paper presented at the 2008 International Arab Conference of eTechnology (IACe-T'2008). Amman, Jordan, October 15-16, 2008.

[3] Kuriloff, P. C. (2001). One size will not fit all. Available online: http://technologysource.org/article/one_size_will_not_fit_all/.

[4] Dabbagh, N. (2001). Authoring tools and learning systems: A historical perspective. Paper presented at the Annual Conference of the Association for Education Communications and Technology. Atlanta, GA, November 8-12, 2001.

[5] Stockley, D. (2003). E-learning definition and explanation (eLearning, online training, online learning). Available online: http://derekstockley.com.au/elearning-definition.html.

[6] Nelson, J. T. (2003). Integration of course management system communication tools in instruction. Unpublished Dissertation, University of Tennessee, Knoxville, TN.

[7] Caplan-Carbin, E. (2003). My beloved Blackboard: Teacher empowerment for students' success. Paper presented at the Annual Conference of the Mid-South Instructional Technology. Murfreesboro, TN, March 30-April 1, 2003.

[8] Morgan, G. (2003). Faculty use of course management systems (Volume 2). Boulder, Colorado: Educause Center for Applied Research. Available online: http://www.educause.edu/LibraryDetail Page/666?ID=ERS0302.

[9] The University of Texas at Austin (2008). Blackboard tutorials: The control panel. Available online: http://www.educause.edu/ LibraryDetailPage/666?ID=ERS0302.

[10] Blackboard Inc. (2008). Blackboard quick tutorials. Available online: $\quad$ http://www.blackboard.com/quicktutorials/quicktutori als.shtm.

[11] Heathfield, S. (2008). Human resources information system: HRIS definition. Available online: http://humanresources.about.com/od/ glossaryh/a/hris.htm.

[12] Moodle (2008). About Moodle. Available online: http://docs.moodle.org/en/About Moodle.

[13] The Florida Diagnostic and Learning Resources System (2008). Interactive whiteboards in the classroom. Available online: http://www.fsdb.k12.fl.us/rmc/tutorials/whiteboards.html.

[14] Hürst W., Müller R., \& Ottmann T. (2004). The AOF method for production, use, and management of instructional media. Paper presented at the International Conference on Computers in Education (ICCE). Melbourne, Australia, November 30-December 3, 2004. 


\section{Challenges of UtILIZING E-LEARNING SYSTEMS IN PUBLIC UNIVERSITIES IN JORDAN}

[15] Alsultanny Y. (2006). E-learning system overview based on Semantic web. Electronic Journal of e-Learning, 4 (2), 111 - 118.

[16] IMS Global Learning Consortium Inc. (2008). Instructional Management Systems. Available online: http://www.imsglobal.org.

[17] Muilenburg, L., \& Berge, Z. L. (2001). Barriers to distance education: A factor-analytic study. The American Journal of Distance Education, 15(2), 7-22. doi:10.1080/08923640109527081

[18] Feeney, D. R. (2001). Rates of adoption in a university course management system. Unpublished Dissertation, West Virginia University, Morgantown, WV.

[19] Rogers, E. M. (2003). Diffusion of innovations (5th ed.). New York: Free Press.

[20] Schifter, C. C. (2000). Factors influencing faculty participation in distance education: A factor analysis. USDLA Journal, 13(1), 113.

[21] Ely, D. P. (2002). Trends in educational technology. (5th ed.). Syracuse, NY: ERIC Clearinghouse on Information and Technology. (ED 477 511)

[22] Al-Shboul, M. A. (2007). Faculty attitudes and perceptions concerning the use of course management systems in higher education. Unpublished Dissertation, Northern Illinois University, DeKalb, IL.

[23] Anderson, J. W. (2003). Faculty perspectives of the Blackboard course delivery system. Paper presented at the Mid-South Educational Research Association (32nd, Biloxi, MS, November 5-7, 2003).

[24] Butler, D. L., \& Sellbom, M. (2002). Barriers to adopting technology for teaching and learning. Educause Quarterly, 25(2), 22-28.
[25] O'Quinn, L. R. (2002). Factors that influence community college faculty participation in distance education. Unpublished Doctoral Dissertation, George Washington University, Washington D.C.

[26] Ndahi, H. B. (1999). Utilization of distance learning technology among industrial and technical teacher education faculty. Journal of Industrial Teacher Education, 36(4), 21-37.

[27] Chizmar, J. F., \& Williams, D. B. (2001). What do faculty want? Educause Quarterly, 24(1), 18-24.

[28] Harrington, C. F., Gordon, S. A., \& Schibik, T. J. (2004). Course management system utilization and implications for practice: A national survey of department chairpersons. Available online: http://www.westga.edu/\%7Edistance/ojdla/winter74/harrington74. htm.

\section{AuTHORS}

Dr. Muhannad Al-Shboul is a member of the Researchers' Association and with the Computer Center, The University of Jordan, Amman, CO 11942 Jordan (e-mail: malshboul@ju.edu.jo).

Dr. Izzat Alsmadi is with the Department of Computer Information Systems, Yarmouk University, Irbid, CO 21163 Jordan (e-mail: ialsmadi@yu.edu.jo).

Manuscript received November $30^{\text {th }}$ 2008. Published as resubmitted by the authors May $24^{\text {th }} 2010$. 